\title{
BUSINESS PROCESS DEVELOPMENT OF SUPPLY CHAIN SYSTEM ON E-COMMERCE LOGISTICS PROVIDER THROUGH QUALITATIVE STUDY
}

\author{
Zakka Ugih Rizqi*, Adinda Khairunisa \\ Department of Industrial Engineering, Universitas Islam Indonesia \\ *ugihzakka@gmail.com
}

\begin{abstract}
E-commerce is growing rapidly in Indonesia. In fact, the number of e-commerce transactions in Indonesia is the largest in Southeast Asia in 2019. This has a major impact on logistics service providers because the e-commerce trading system requires logistical intermediaries between sellers and buyers. Therefore, logistics companies are developing rapidly to achieve this opportunity so that each company competes to become the best logistics company. Companies become competitive if they have a good business process. So that the effectiveness and efficiency of the supply chain are two important things so that the company becomes sustainable. This research is basically qualitative study where the business process development of PT Z is carried out to enhance the efficiency and effectiveness of the supply chain through Focus Group Discussion (FGD) and Benchmarking. Through a systematic process, more effective and efficient business process are obtained from the perspective of information flow, financial flow, and flow of goods.
\end{abstract}

Keywords: E-Commerce, Business Process, Qualitative Study, Supply Chain

Received 20 February 2020 Accepted 25 May 2020 Available online 24 June 2020

\section{INTRODUCTION}

E-commerce is now a trading system that is used by almost people in the world. In Indonesia, E-commerce is growing rapidly that makes the e-commerce transactions in Indonesia to be the largest in Southeast Asia in 2019 to reach US \$ 21 billion (1) and it is projected to have a positive trend (2). This has a big impact on logistics providers, considering that the e-commerce trading system requires logistics services between sellers and buyers (3).

Every logistics service provider company or Third-Party Logistics (3PL) competes to improve its supply chain system in order to increase customer satisfaction. Customer satisfaction is obtained when the 3PL company can ensure delivery of goods ordered by customers so that they can be delivered on time, on product, on quantity, on price, on recipient, and on quality (4). Therefore, the effectiveness and efficiency of the supply chain are very important for 3PL companies to survive and grow.

In this study, the development of e-commerce business process at PT Z as a logistics company in Indonesia was carried out to enhance the efficiency and effectiveness of the supply chain through qualitative study. Qualitative study is a form of analysis that is based on experience, trust, and interpretation from the perspective of each individual that aims to describe the issue systematically and then generate new concepts (5)(6). The method used is Focus Group Discussion (FGD) and Benchmarking. FGD is a method for obtaining data/information through the social interactions of a group of individuals who in that interaction, fellow individuals influence one another (7). While benchmarking is a tool for comparing competitive advantages between companies so that superior performance is obtained (8)(9)(10). Through these methods, broader insights and ideas will emerge in groups of individuals in 
business process and supply chain. The result of this study is in the form of a more efficient and effective business process that benefits every stakeholder in the e-commerce logistics.

\section{RESEARCH METHOD}

The FGD was carried out with a focused discussion containing several stakeholders such as 4 experts who were experienced in e-commerce logistics as a source of information, researchers who designed the FGD process, and moderators who organized the discussion in an informal setting. The FGD was divided into three stages, namely: a) The development of information flow, b) The development of cash flow, and c) The development of the goods flow. In the flow of information, it is related to the information to support the buying and selling activities such as order notification, receipt number notification, order tracking, and so on. In the flow of money, it shows the movement of money from buyers to sellers and PT Z as a logistics service provider through the marketplace. While the flow of goods shows the movement of goods from the seller until received by the buyer.

Each stage takes place in several parts. In the first part, the benchmarking process is done by comparing the company's current business process with competitor's business process. In other words, benchmarking is done as a way to get inspiration in making a differentiation towards a better direction. In the second part, each expert is given the same time to give an advice. In the third part, each expert provides criticism and suggestions for each expert's opinion. In the fourth part, all experts discuss and choose the best advice based on the results of the voting of experts. Some parameters used in the selection are the availability of funds owned by PT Z, the availability of technology and other supporting resources, and the willingness of stakeholders (especially the marketplace) to modify the supply chain system considering that the supply chain is a network which affects all stakeholders and not only the company's internal system.

\section{FINDING AND DISCUSSION}

\section{The Proposed Business Process}

The FGD and benchmarking results in the form of an innovative e-commerce logistics provider business process where the marketplace-seller-logistics provider-buyer becomes an integrated bond so as to facilitate each stakeholder by implementing e-logistics illustrated in Figure 1 and the description is shown in Table 1 .

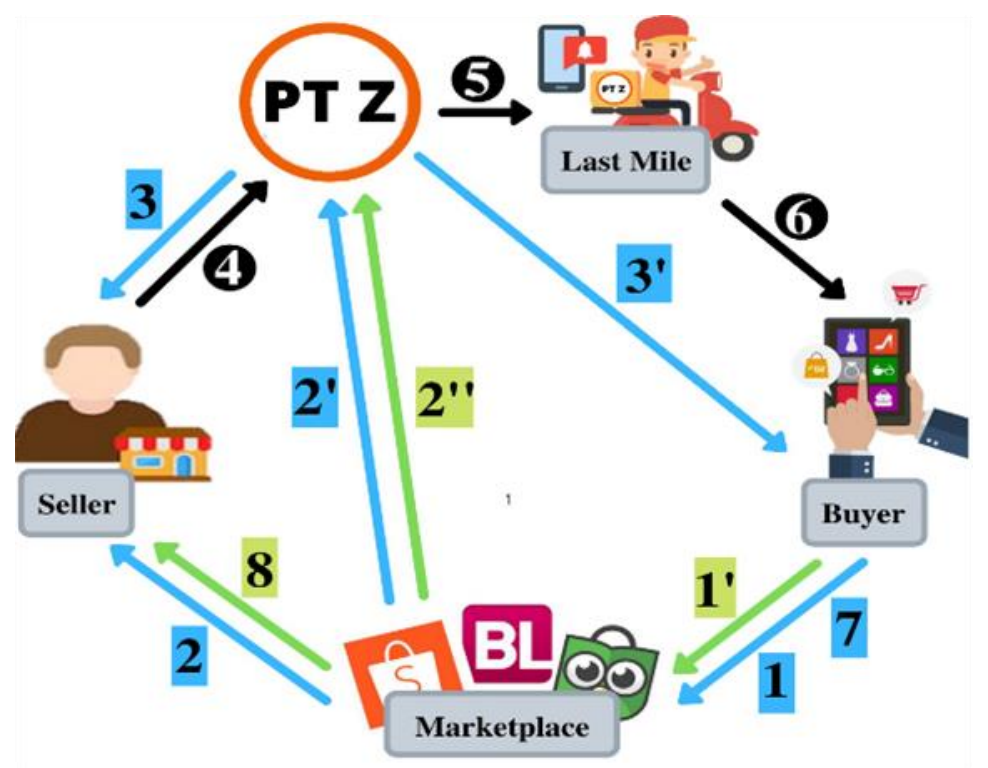

Figure 1. Business process development 
Table 1. Description of business process development

\begin{tabular}{|c|c|}
\hline No & Activities \\
\hline & Buyers order goods in the marketplace and complete the payment to the marketplace. \\
\hline $22^{\prime} 2^{\prime \prime}$ & $\begin{array}{l}\text { The marketplace system sends order notifications to sellers and to the PT Z system via } \\
\text { the API (Application Programmable Interface) while sending payment service delivery } \\
\text { to PT Z. }\end{array}$ \\
\hline 3 & $\begin{array}{l}\text { PT Z sends a QR-Code to the seller \& buyer e-mail address containing the receipt } \\
\text { number. }\end{array}$ \\
\hline & $\begin{array}{l}\text { The seller obtains the QR-Code and then takes the item to the PT Z branch/outlet by } \\
\text { showing the QR-Code. }\end{array}$ \\
\hline & $\begin{array}{l}\text { PT Z receives the goods and scans the QR-Code (information about the name, } \\
\text { address, and telephone number of the buyer has entered the PT Z network system } \\
\text { through an integrated e-logistics system without the need to manually input the } \\
\text { computer. The location of the item will be updated on the tracking system that can be } \\
\text { seen by buyers on the PT Z website). } \\
\text { - PT Z packs the goods and attaches the printed QR-Code which is then coated by } \\
\text { wrapping plastic. Delivery of goods according to the schedule that has been set } \\
\text { (using the algorithm). }\end{array}$ \\
\hline & $\begin{array}{l}\text { Last Mile PT Z delivers goods by scanning QR-Code in advance (the buyer's address is } \\
\text { tracked directly on Google Maps using integration with the Google Maps plug-in and } \\
\text { directly connected to the buyer's WA number thereby reducing the risk of lost couriers). }\end{array}$ \\
\hline 7 & Buyers receive goods and confirm that they have received goods in the marketplace. \\
\hline 8 & Marketplace pays the price of the item to the seller. \\
\hline
\end{tabular}

\section{Business Process Differentiation}

The results of the FGD and benchmarking produce a differentiation regarding the business process of e-commerce logistics by PT Z which implements e-logistics compared to other logistics service providers generally who still implements conventional logistics process. A comparison between PT Z and competitors is shown in

Table 2. The differentiation of business process

\begin{tabular}{|c|c|c|c|}
\hline \multirow{2}{*}{ No } & \multirow{2}{*}{ Stage } & \multicolumn{2}{|c|}{ E-Commerce Logistics Provider } \\
\hline & & Competitors & PT Z \\
\hline 1 & Seller sends goods & Seller brings goods to the outlets & Seller brings goods to the outlets \\
\hline 2 & $\begin{array}{l}\text { Administrative } \\
\text { replenishment of goods to } \\
\text { be sent }\end{array}$ & $\begin{array}{l}\text { Fill in the blank at the outlets by } \\
\text { the employee }\end{array}$ & Filled via application \\
\hline 3 & Packaging the goods & $\begin{array}{l}\text { Packed at the outlets by the } \\
\text { employee }\end{array}$ & $\begin{array}{l}\text { Packed at the outlets by the } \\
\text { employee }\end{array}$ \\
\hline 4 & $\begin{array}{l}\text { Attachment of buyer's } \\
\text { address }\end{array}$ & $\begin{array}{l}\text { Performed manually by } \\
\text { employees in outlets }\end{array}$ & $\begin{array}{l}\text { Addresses and administration } \\
\text { are printed out in the form of } \mathrm{QR} \\
\text { Code }\end{array}$ \\
\hline 5 & Weighing goods & $\begin{array}{l}\text { Performed by employees at the } \\
\text { outlets using the scales }\end{array}$ & $\begin{array}{l}\text { Goods weight data is obtained } \\
\text { directly from the marketplace }\end{array}$ \\
\hline 6 & Payment & $\begin{array}{l}\text { Using bank transfer (e-banking or } \\
\text { m-banking) }\end{array}$ & $\begin{array}{l}\text { Using bank transfer (e-banking } \\
\text { or m-banking) }\end{array}$ \\
\hline 8 & Warehousing management & $\begin{array}{l}\text { Performed by warehouse } \\
\text { employees }\end{array}$ & $\begin{array}{l}\text { Performed by warehouse } \\
\text { employees }\end{array}$ \\
\hline 7 & $\begin{array}{l}\text { Delivery Scheduling } \\
\text { Management }\end{array}$ & $\begin{array}{l}\text { Delivery scheduling is calculated } \\
\text { using an algorithm manually }\end{array}$ & $\begin{array}{l}\text { Optimal scheduling is obtained } \\
\text { through the application of } \\
\text { Artificial Intelligence }\end{array}$ \\
\hline
\end{tabular}




\begin{tabular}{|c|c|c|c|}
\hline \multirow{2}{*}{ No } & \multirow{2}{*}{ Stage } & \multicolumn{2}{|c|}{ E-Commerce Logistics Provider } \\
\hline & & Competitors & PT Z \\
\hline 9 & Goods delivery - inner city & Delivered by courier & Delivered by courier \\
\hline 10 & Goods delivery - outer city & Fleet/3PL Partner & Fleet/3PL Partner \\
\hline 11 & $\begin{array}{l}\text { Searching of buyer's } \\
\text { address by courier }\end{array}$ & $\begin{array}{l}\text { Based on the address paper } \\
\text { attached to the goods }\end{array}$ & $\begin{array}{l}\text { The courir scans the QR Code to } \\
\text { track the recipient's address } \\
\text { which is integrated with the } \\
\text { Google Maps plug-in }\end{array}$ \\
\hline 12 & Goods tracking & Web-based tracking system & Web-based tracking system \\
\hline 13 & $\begin{array}{l}\text { Collecting proof of goods } \\
\text { receipt by the buyer }\end{array}$ & Through a note of the courier & $\begin{array}{l}\text { The buyer confirms receipt of } \\
\text { goods on the application }\end{array}$ \\
\hline 14 & $\begin{array}{l}\text { Customer satisfaction } \\
\text { assessment }\end{array}$ & Survey & $\begin{array}{l}\text { Digital rating on application and } \\
\text { website }\end{array}$ \\
\hline 15 & Customer complaints & Manual on the service center & Through real-time applications \\
\hline
\end{tabular}

\section{CONCLUSION}

Through a qualitative study conducted systematically with several experts, this study produces PT Z's business process that is more effective and efficient from the perspective of information flow, financial flow, and goods flow so as to facilitate each stakeholder involved and make PT $\mathrm{Z}$ more sustainable. It can be achieved by implementing digital technology or e-logistics. Even though the proposed business process will provide a large investment, the company keeps confidence that it will get a large return on investment and profits in the future considering the big market opportunity for the e-commerce logistics provider in Indonesia that is always increasing rapidly every year.

\section{ACKNOWLEDGEMENTS}

The authors thank Universitas Islam Indonesia for helping with the funding of this research and for all the experts who provided advice and participation in this research. Authors are also grateful to reviewers who have made this paper better.

\section{REFERENCES}

1. Y. Pusparisa, Transaksi e-commerce Indonesia terbesar di Asia Tenggara [Internet]. 2019 [cited 2019 Oct 14]. Available from: https://databoks.katadata.co.id/datapublish/2019/10/10/nilai-transaksi-digitalperdagangan-elektronik-indonesia-terbesar-di-asia-tenggara

2. D.H. Jayani, Tren pengguna e-commerce terus tumbuh [Internet]. 2019 [cited 2019 Oct 14]. Available from: https://databoks.katadata.co.id/datapublish/2019/10/10/trenpengguna-e-commerce- 2017-2023, 2019

3. R. Rahmidani, Penggunaan e-commerce dalam bisnis sebagai sumber keunggulan bersaing perusahaan. In: Seminar Nasional Ekonomi Manajemen \& Akuntansi, 2015. p. 344-52.

4. Zaroni, Logistik e-commerce [Internet]. 2015 [cited 2019 Oct 20]. Available from: http://supplychainindonesia.com/new/logistik-e- commerce/

5. A. Tong, K. Flemming, E. McInnes, S. Oliver, J. Craig, Enhancing transparency in reporting the synthesis of qualitative research: ENTREQ. BMC Medical Research Methodology, 12 (2012) 181.

6. A.P. Viswambharan, K.R. Priya, Documentary analysis as a qualitative methodology to explore disaster mental health: insights from analyzing a documentary on communal riots, Qualitative Research, 16 (2016) 43-59.

7. P. Lehoux, B. Poland, G. Daudelin, Focus group research and "the patient's view", Social 
Science \& Medicine, 63 (2006) 2091-104.

8. A. Booth, The Economics of The Trade Union. Cambridge University, 1995.

9. J.G. Patterson, Benchmarking basics: looking for a better way, Manlow Park, California: Crisp Publications, 1996.

10. R. Venetucci, Benchmarking: A reality check for strategy and performance, Production and Inventory Management Journal, 33 (1992) 32-9. 